Revistade
Economild
Contemporâned

\title{
INSTITUTIONS AND ENVIRONMENTAL GOVERNANCE IN BRAZIL: THE LOCAL GOVERNMENTS' PERSPECTIVE
}

\author{
Estela Maria Souza Costa Neves ${ }^{a}$

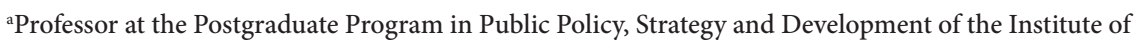 \\ Economics, at Federal University of Rio de Janeiro.
}

Manuscript received on 2015/10/23 and accepted for publication on 2016/11/21.

\begin{abstract}
This paper explores some of the institutional factors that guide the environmental action of municipalities in Brazil. The starting premise is that there are particular institutional factors that empower the Brazilian state and society, guide processes and provide a unique profile to local environmental policy. Regulations for environmental protection are analysed from a historical perspective, taking into account the federal organization of the Brazilian state and its particular distribution of powers. Five factors emerge as the driving forces behind the actions taken by municipalities in relation to the environment: the federal status of municipalities, the inclusion of the environmental protection provision in the Federal Constitution, the lack of consistent funding for environmental policy, the coexistence of several regimes within environmental rules, and the discretionary power, held by environmental bureaucracy, related to the indeterminacy of environmental regulation.
\end{abstract}

KEYWORDS: institutions; environmental law; environmental policy; Brazil; local government.

JEL CODES: K320; H770.

Corresponding author: Estela M. S. C. Neves

Email address: Estela.neves@gmail.com 


\section{INSTITUIÇÕES E GOVERNANÇA AMBIENTAL NO BRASIL: A PERSPECTIVA DOS MUNICÍPIOS}

RESUMO: Neste artigo são analisados, em caráter exploratório, fatores institucionais que balizam a ação dos municípios brasileiros no campo ambiental. Assume-se como ponto de partida que determinados condicionantes institucionais habilitam Estado e sociedade para a tutela da qualidade ambiental no Brasil, balizando processos de políticas públicas ambientais e definindo singularidades do exercício do mandato ambiental na esfera municipal. A análise aborda regulações ambientais de abrangência nacional em perspectiva histórica, à luz da organização federativa do Estado no Brasil e da distribuição entre esferas de governo. Cinco fatores se destacam como forças motrizes das ações municipais no campo ambiental: o status dos municípios enquanto entes federativos, a inclusão do tema ambiental na Constituição federal, a ausência de provisões para garantir fontes estáveis de financiamento da política ambiental, a coexistência de diversos regimes jurídico-institucionais na moldura institucional ambiental, e o poder discricionário da burocracia ambiental, relacionado à indeterminação da norma ambiental.

PALAVRAS-CHAVE: instituições; regulação ambiental; política ambiental; Brasil; município; governo local. 


\section{INTRODUCTION}

Institutions have a strong shaping power over public policy and mechanisms of governance. Regarding the environment, institutions are simultaneously responsible for causing problems and for structuring collective action to address these problems (YOUNG, 2008). If institutional influence is disregarded in the design of environmental governance systems and policies, these will be doomed ex ante. Recently, there has been growing interest in the role of institutions in environmental politics and policies. Nevertheless, much remains to be investigated with respect to institutional issues related to environmental policy and governance.

As in many other countries, in Brazil stewardship of the environment by the state has a reasonable history: the authorities' obligation to provide environmental protection has been in force for almost 40 years, both object and driver of significant institutional changes. These changes and their effects have been object of some academic inquiry, but the subject is still largely unexplored. In order to fill this gap, this paper focuses on the Brazilian environmental regulation, exploring the institutional factors that guide the environmental actions of municipalities.

The starting premise is that there are particular institutional factors that empower the Brazilian state and society, guide processes, and provide a unique profile to environmental policy across the domains of state action, defining in a singular manner each sphere of government's field of action, as well as civil society actors. The literature that tackles institutional changes in the realm of the environment is relatively recent, rather limited, and based on varied theoretical traditions (VATN, 2005). For the sake of this study, the state is defined as both an institution and a particularly important actor (EVANS, 2014). According to Hodgson (2006, p.6), laws may be considered as institutional rules when they are "(...) enforced to the point that the avoidance or performance of the behavior in question becomes customary and acquires a normative status". Regulations concerning environmental protection should necessarily be analysed from a historical perspective, recognizing that states are "(...) complex, diverse and heterogeneous in terms both of their characteristics and in the ways they relate to society [and] to the economy" (HODGSON, 2006, p.17). In Brazil, the institutional analysis should also take into account the federal organization of the Brazilian state, its particular trajectory and the distribution of powers among the three tiers of government - Federal government, states and municipalities.

The results of this inquiry, developed through an exploratory institutional analysis of federal environmental legislation and the specialized literature on Brazilian environmental law and policy, follow in three parts. The first section analyses the institutionalization process of the environmental law in Brazil from a historical perspective, in which four 
stages are distinguishable. The second section examines five key factors that enable the understanding of state environmental action at the local level: the inclusion of municipalities among the federated entities, the inclusion of the environmental protection provision in the Federal Constitution, the lack of consistent funding for environmental policy, the coexistence of several regimes within environmental rules, and the discretionary power related to the indeterminacy of environmental regulation. Third section discusses how those five key institutional changes shape municipal action to accomplish its environmental mandate and presents concluding remarks.

\section{THE COSTRUCTION OF AN INSTITUTIONAL MATRIX FOR BRAZIL'S ENVIRONMENTAL POLICY}

The 1980s are unanimously considered a milestone era in the construction of the institutional framework for Brazilian environmental policy. However, important references do exist in earlier laws, prior to the emergence of the environment as a matter of public concern around the world. Research on environmental history demonstrates there has been discussion of environmental issues and their effects in Brazil since the late $18^{\text {th }}$ century (PÁDUA, 2000). Laws containing environmental provisions date to the early Portuguese colonial administration. They remained in force until the Civil Code of 1916 (WAINER, 1997 apud MILARÉ, 2014). These, far from striving to protect environmental assets, were typically intended to ensure the survival of a particular resource, such as Brazil wood trees, that were subject to accelerated depletion (BENJAMIN, 2003).

There is somewhat less consensus regarding the periodization of the trajectory of Brazilian environmental policy in its entirety. In the literature on Brazilian environmental law, several distinct historical frameworks have been employed, testifying to the richness of approaches offered by various disciplines. Neder (2002) identified three roots of environmental regulation: the geopolicy of creating protected areas, starting in the 1930s; the industrial zoning policy, arising out of the environmental management of the 1970s; and the debate on the relation between the environment and sustainable development, which blossomed in the 1990s.

From the viewpoint of environmental law, Benjamin describes three "regimes" in the evolution of Brazilian environmental law, corresponding to "three ethical-legal valuations of the environment," which, far from being sharply defined and successive, overlap in time. These are the unregulated exploitation or laissez-faire phase (extending from the sixteenth century until the middle of the twentieth century); the fragmentary phase, focusing on the natural resources by sector (from the late 1950s until the early 1980s); and the holistic phase, starting in 1981, "an integrated ecological system, with 
evaluative autonomy, [the environment] is, in itself, a legal asset, with mandatory rights” (BENJAMIN, 2003, p.17).

Inspired by the "regimes" described by Benjamin, this paper outlines a tentative periodization of the process of institutionalization of Brazilian environmental policy in four phases ${ }^{1}$. The beginnings and endings of these phases are deliberately imprecise, reflecting the coexistence and overlapping of different regimes. The periods are: the "prehistory" of environmental policy (late nineteenth century until the late 1960s); the sectorial approach to environmental protection (late 1960s to early 1980s); the structuring of the institutional framework (1980s); and the consolidation of the institutional framework (early 1990s through 2010). The evidence strongly suggests a new inflection in the early 2010's towards the weakening of the environmental institutional framework, such as the movement in the National Congress to weaken the Forestry Code of 1965, culminating in its replacement at the end of 2012, the relaxing of restrictions related to the status of protected areas, and the unsatisfactory Complementary Law 140/2011 that diminished federal government power on environmental control.

\subsection{THE "PREHISTORY" OF BRAZILIAN ENVIRONMENTAL POLICY}

During this first period, from the late nineteenth century until the 1960s, scattered laws are to be found with the first references being to environmental resources as matters of public interest, under state supervision. The first Brazilian law to enforce environmental protection was the Criminal Code of 1890, which defined as a crime the pollution of any source of drinking water - this was called "poisoning" (CARVALHO, 2003a). Up until the 1930s there were just a few other statutes, touching on neighbour behavior capable of polluting or rendering useless water wells or springs not on one's own property (in the Civil Code of 1916) ${ }^{2}$, and standards for industrial and occupational hygiene (in the Public Health Regulations of 1923) ${ }^{3}$.

Between the 1930s and the late 1960s, several government initiatives foreshadowed current environmental regulation. The rules focused on the safeguarding of natural resources and sanitation, establishing the public stewardship of environmental assets and

1 The topic was studied by Silva (2009); Wainer (1997); Neder (2002); Silva-Sanchez (2003); Carvalho (2003b); Benjamim (2003); McAllister, 2008; Machado (2014); and Milaré (2014).

2 The three essential neighborhood rights are peace and quiet, safety, and healthy living conditions. In the Civil Code, Law 3,071 of 01/01/1916, articles 554 and 584, were replaced by Law 10,406 of 01/10/2002.

3 Decree 16,300 of 12/31/1923. This Rule also defines healthy occupational conditions for workers. 
defining requirements for their economic exploitation. A conservationist approach characterizes these centralized regulations concentrated at the federal level, which were associated with the federal government's attempt to control over the national territory (NEDER, 2002). The first regulations describing natural resources, to be treated as assets of the public interest, were passed during the first Vargas government (1930-1945). The most important of these were the Water Code of 1934, addressing the industrial use of water and hydropower generation, and the Forestry Code, also of 1934, inaugurating the understanding of forests as "assets of public interest" (art. $1^{\text {st }}$ ), and the creation of the first instrument for state safeguarding of large areas of preservation interest, the parks. This era saw the enactment of similarly intentioned laws, such that which initiated the listing of selected buildings as cultural heritage in 1937, and the Fisheries Code of 1938 for the management of fishing activities. The next wave of legislation did not arrive until the 1960s, with the enactment of the Land Statute, the Hunting Code, and the National Policy for Basic Sanitation of 1967, the last launching a nationwide sanitation program, with the federal government funding state agencies. The Forest Code was reviewed in 1965 and a new category of protected area was added, the National Forest. Regulating agencies such as the Federal Institute for Forest Management ${ }^{4}$ - were created for the stewardship of natural resources, on the principle of federal jurisdiction over these assets.

\subsection{A SECTOR-BY-SECTOR APPROACH TO ENVIRONMENTAL PROTECTION}

In the second period, covering approximately twenty years (from the late 1960s to the early 1980s), new laws addressed environmental issues as objects of sectorial policy, such as industrial pollution, protecting large areas and tackling the allotment of urban land, nationwide. During the 1970s, pollution control rules were established, punishing pollution caused by ships and maritime terminals and inaugurating the control of industrial pollution, by zoning industries on pollution-critical areas. Two more categories of conservation areas were created: the Environmental Protection Areas and Ecological Stations, areas set aside for scientific research ${ }^{5}$. Concern about the widespread problems in urban areas due to accelerated and chaotic development resulted in the creation of the Lehmann Law in 1979, which established basic national parameters for the allotment of urban land, including environmental requirements for lot zoning and the protection of environmentally sensitive areas ${ }^{6}$.

\footnotetext{
4 Instituto Brasileiro de Desenvolvimento Florestal, created in 1967 (Federal Decree n. 289).

APA - Áreas de Proteção Ambiental and ESEC - Estações Ecológicas created by Law 6,803 of 07/02/1980.

6 Law 6,766 of 12/19/1979, currently under review.
} 
The first mention of environmental issues in national policies is made in the national development plan during the mid-1970s ${ }^{7}$. Environmental regulation was hitherto concentrated at the central (federal) government level. Nevertheless, for key issues such as environmental control and granting of permits for specific activities, this power was shared with state governments. The first public agencies for environmental protection were, at the federal level, the Special Secretary's Office for the Environment (SEMA - Secretaria Especial de Meio Ambiente), and the state-level secretary's offices in the states of Minas Gerais, Rio de Janeiro, and São Paulo. The state environmental agencies were responsible for enforcing the new industrial pollution control regulations, implementing environmental permitting, and setting up a network encompassing these state agencies and the federal agency, in a so-called "guerrilla strategy" (FRANCO, 2002). At the municipal level, initiatives were scarce but pioneering, and included the creation of the first local environmental agency in Porto Alegre, Rio Grande do Sul (1976) ${ }^{8}$. Municipal, bottom-up initiatives were expressions of the political will of local authorities to address the institutional terrain of environmental protection, based on the principle of municipal local interest. These are all the more surprising when one considers that there were no incentives for municipalities to get involved in environmental governance.

During this phase, environmental regulation initiatives were developed under the hostile political environment of the military dictatorship 9 . However, several of them report to the outlined international discussion of the relation between economic growth and the finitude of natural resources, a discussion spurred by The Limits to Growth, a 1972 study published by the Club of Rome. Thus, in a certain extent the Brazilian new rules constitute a response to the debate at the Stockholm Conference of 1972 and reflect a shift in the Brazilian government's position during the meeting (NOGUEIRA NETO, 2003).

\subsection{THE STRUCTURING OF A NATIONAL INSTITUTIONAL FRAMEWORK FOR ENVIRONMENTAL PROTECTION}

The third period consists of the 1980s, when state environmental action took on a systemic character. As pointed out, there were several important milestones (MILARÉ,

\footnotetext{
7 Second National Development Plan, 1974-1979, Law 6151 of 12/04/74, unfolding into Decree 1413/75 and Decree 76,389/75, providing for the control of industrial pollution, and Ordinance $1301 / 15 / 76$, on the classification of national inland waters.

8 Followed by Belo Horizonte/ MG (1983) and some other municipalities.

9 The mentioned dictatorial regime in Brazil lasted from 1964 to 1985.
} 
2014; MACHADO, 2014; SILVA, 2014). Playing a pioneering role in Latin American and the Caribbean, in 1981 the Brazilian federal government recognized the state responsibility for environmental protection and instituted a national environmental policy through federal law, establishing principles, goals, instruments, and a framework for national management of the environment. These innovations would be strengthened a few years later to an unprecedented degree: in the Constitution of 1988 the National Constituent Assembly raised them to the status of constitutional provisions.

These breakthroughs followed three significant changes put in place in 1985: the inclusion of the environment as a diffuse and collective interest under the responsibility of public prosecutors (the Ministério Público); the mandating of public prosecutors to assume responsibility for environmental regulation enforcement, particularly through the bringing civil lawsuits against offenders, enabling this powerful, independent supervisor both of the society and of the three government spheres; and the establishment of the principle of strict liability ${ }^{10}$.

The governance model was consolidated as the National Environmental System (SISNAMA), which in 1981 designed the Brazilian environmental policy matrix based on shared responsibility among the federal, state and municipal levels ${ }^{11}$. According the national environmental policy in place, municipalities had the same responsibilities as the states and the federal government, with equal legislative power over environmental issues based on their local interest, in spite of the former only being considered a political-administrative member of the federation seven years later ${ }^{12}$.

Over the third period, the federal government agenda for environmental protection was organized around four priorities: the establishment of emission and ambient quality standards, control of air and water pollution, the granting of environmental permits being contingent upon environmental impact studies; the protection of urban and regional watersheds and management of conservation areas. This agenda was associated with the expansion of the environmental movement throughout the country and the intensification of pressure, both domestic and abroad, to address issues such

\footnotetext{
10 Law 7,347 of 1985.

11 SISNAMA is formed by the environmental organs and entities of the Federal Government, of States and Federal District, of the Municipalities, and by several Foundations established by the public power to address the protection of the environment. Its structure is composed of a higher body, a consultative and deliberative body, a central organ, an executing agency, sectional agencies, and local bodies. The higher body was formally assigned to the Governing Council, but never actually exercised its function. According to Milaré (2004), in practice, this role is held by the National Environmental Council CONAMA, the consultative and deliberative organ, considered the largest organ in the system, chaired by the Ministry of the Environment.

12 See Law 6,938, art. 4, III; arts. 5, art.6, \# 1, 2 and 3.
} 
as the critical industrial urban pollution in Cubatão (São Paulo) and the damages caused by high-impact, large-scale hydroelectric plants in the Amazon region ${ }^{13}$.

Using the federal and state-level agencies (of those with large metropolitan areas which had required industrial pollution management) created in the previous decade, the new system was soon implemented nationwide, focused on environmental control: inspecting, permitting and monitoring. State-level environment protection agencies (those of Rio de Janeiro, São Paulo, and Minas Gerais) trained the technical staff of the new agencies of other states, providing them with adequate capacities and resources for environmental protection. At the federal level, the end of the 1980s saw the creation of the National Fund for the Environment (FNMA) ${ }^{14}$ and the all-important Brazilian Institute for the Environment (IBAMA), an executive federal environmental agency with a great deal of power ${ }^{15}$. The institutional framework for environmental policy, which saw the light of day during the darkest period of the authoritarian regime, nevertheless had a democratic, innovative design, having been inspired by the experiences of the agencies in Minas Gerais and Rio de Janeiro (CARVALHO, 2003b) ${ }^{16}$.

The 1988 Constitution endorsed the initiatives that had been put forth since the beginning of that decade, endowing them with the status of constitutional provisions with decisive support from the parliamentary Green Front. The Green Front had mobilized to push to the fore the environmental debate during the drafting of the new constitution. In the approved text, the environmental issue was linked to economic and social development; public prosecutors (or "Public Ministry") were reaffirmed as the legal advocates for citizens and civil society organizations, and as guardians of the environment and of other diffuse public and collective interests; the principle of strict

13 The hydroelectric dams of Tucuruí, Balbina and Samuel are examples of high-impact dams in the Amazon.

14 The FNMA was created by Law 7,797 of 07/10/1989 and regulated by Decree 98,161 of 09/21/1989. The FNMA is mandated with developing projects that promote the rational and sustainable use of natural resources, addressing with priority conservation areas, research and technological development units, environmental education, forestry management, institutional development, environmental control, and the rational and sustainable economic use of native flora and fauna. It is managed by a Deliberative Council with thirteen members and functions under the Ministry of the Environment.

${ }^{15}$ IBAMA was created with the merger of four administrative bodies, the Special Secretary for the Environment (SEMA), the Brazilian Institute for Forestry Development (IBDF), the Superintendency for Fisheries Development (SUDEPE) and the Superintendency for Rubber, (SUDHEVEA). Since 2007 IBAMA shares responsibilities with Instituto Chico Mendes de Conservação da Biodiversidade, responsible for the policies related to protected areas (in Portuguese, Unidades de Conservação).

${ }^{16}$ Law 6,938/1981, of 08/31/81, was surprisingly approved with a practically unanimous vote. Nogueira Neto (2003) reports that only two congressmen voted against it; subsequent presidential veto trimmed down only two articles of the law. For political reasons, its regulation was postponed for 1983, delaying its enforcement. 
liability with sanctions in civil, administrative, and criminal law was enshrined, inaugurating a "prosecutorial mode of enforcement that has reshaped environmental enforcement in Brazil" (MCALLISTER, 2008). The distribution of environmental competencies allotted in 1981 was substantiated through the definition of the environmental protection as a common responsibility. This included the raising of the municipalities, for the first time, to the status of federated entities in the Constitution of 1988 and putting them from that point forward on an equal footing with the state and federal governments.

\subsection{THE CONSOLIDATION OF THE INSTITUTIONAL FRAMEWORK}

The fourth period was characterized by the gradual improvement and expansion of the environmental institutional framework and policies. This period began in the 1990s and extended for twenty years until the end of the 2000s/early 2010s. The II United Nations Conference on Environment and Development (UNCED) or "Earth Summit," held in Rio de Janeiro in June of 1992, decisively influenced the environmental agendas of a number of countries, including Brazil, as well as the international agenda, with its discussion of the so-called "global environmental problems" as environmental degradation was correlated to unsustainable patterns of production and consumption, poverty, urbanization, and international trade ${ }^{17}$.

Criminal accountability for environmental offences was consolidated as the Environmental Crimes Law (1998) ${ }^{18}$. With this law, environmental regulation became complete and covered the civil, administrative, and criminal spheres. Pre-existing instruments that had established criminal sanctions, such as for the causing of harm to the waters or to fishing resources, had been fragmented. The innovations under this law were the systematization of penalties forpollution offenses, compiling a list of almost all of the environmental criminal offenses, establishing the criminal liability of legal entities, and criminalizing the misbehavior of environmental managers (BENJAMIN, 2003; MARCHESAN and STEIGLEDER, 2013).

New regulation and frameworks were adopted for water resources protection and management (1997), inspired by experiences in the U.S. and France. Rules regarding protected areas and educational activities related to environmental protection were enacted on a national scale and improved (2000). In the first decade of the current

\footnotetext{
17 Heldin Rio de Janeiro, Brazil, in 1992.

18 Law 9,605/1998.
} 
century, the arsenal of environmental policy instruments was strengthened by the guidelines for the national urban development policy rooted in the environmental paradigm (City Statute of 2001) ${ }^{19}$. In 2007, federal laws regulating basic sanitation were finally passed, also framed within the environmental paradigm and conceived as a universal service ${ }^{20}$. The issue, the core of the so-called "Brown Agenda," had been left on the back burner for over twenty years, providing the institutional basis for subsequent federal regulation of sanitation and solid waste ${ }^{21}$. Finally, the National Congress approved several federal laws related to a significant body of international agreements signed by Brazil, on various subjects such as biodiversity conservation and climate change.

The institutional framework for environmental protection was supported by the building of capacities, skills, and organizational resources through the implementation of the National Environment Program (PNMA - Programa Nacional de Meio Ambiente). This federal government initiative, funded by the World Bank and the Kreditanstalt fur Wiederaufbau (KfW), focused on the institutional strengthening of environmental policy at the state and federal government levels. In spite of the lack of formal support for capacity building at local level, decentralization of environmental management advanced with the creation of municipal environmental agencies, invariably in the larger and economically more dynamic municipalities.

The reforms launched in Brazil in the 1980s included the implementation of a neoliberal-inspired agenda to bring about the country's integration into the global economy. The key elements of this agenda were economic deregulation and market liberalization and stabilization (REZENDE and AFONSO, 2004). The enforcement of environmental regulations and policies went against the tenets of the neoliberal agenda, impaired by restrictions arising from the reforms and accompanied by tight fiscal discipline, the adoption of a new public management model. On the other hand, the national environmental agenda also stimulated the cooperation of the state with civil society organizations and the private sector (FARAH and JACOBI, 2000). Environmental agencies demanded - with scant success - investment to support the structuring of organizations, the training of a specialized bureaucracy, and the building of the tools and programs needed to perform their assigned duties, all which ran counter to the trend toward reducing the size of the federal government and restricting public spending.

\footnotetext{
19 Law 10,257/2001.

20 Law 11,445/2007.

${ }^{21}$ Law 12,305/2010.
} 


\subsection{THE THREATENING OF THE INSTITUTIONAL MATRIX}

It is imperative to recognize a turning point in the development of the national environmental framework that occurred in the beginning of the present decade. Evidence strongly suggests a new trend towards the weakening of the institutional matrix, such as the movement in the National Congress to attack the Forestry Code of 1965, culminating in its replacement at the end of 2012, the relaxing of the status of protected areas and of environmental licensing rules, threats to indigenous areas and the unsatisfactory Complementary Law 140/2011, which remains in force.

Evidence of a countermovement was visible by the end of the second Lula administration (2007-2010) (see, for example, in Valle, 2010). Vested interests in the National Congress took major steps towards the deliberate dismantling of crucial elements in the institutional framework for environmental protection. Mainly promoted by the so-called "ruralist" or conservative landowner, caucus in Congress, efforts to reform forestry law were finally successful, as the Forestry Code (2012) was replaced with far weaker rules that allow, for example, the reduction of the Permanent Preservation Areas and of the mandatory percentages of wooded acreage conservation in each state, and the pardoning of fined loggers ${ }^{22}$. The setback represented by these new rules, at least in some areas, is already verifiable through field research, such as that done in the state of Mato Grosso (ISA, 2015). In addition, the creation of new protected areas was curtailed, the reduction of conservation areas in the Amazon was passed through a provisional measure, the legalizing of indigenous reserves was frozen, and proposals were floated to allow mining in indigenous land and environmental permitting in cases with glaring social and environmental problems (BERNARD, PENNA and ARAUJO, 2014) ${ }^{23}$.

Receiving very little attention from the media, and practically ignored in both academic circles or in the public administration, were further changes made at the end of 2011 through a Federal Constitution supplemental law designed to regulate the forms of environmental cooperation among the three federal levels: the Federal government, the States, and the Municipalities ${ }^{24}$. This rule did not achieve its mandated purpose - to regulate intergovernmental cooperation to ensure common competence in environmental protection - as will be discussed in the following section.

It lies beyond the scope of this study to analyse these legal changes in detail or to explore their main outcomes. The intent at hand is exclusively to highlight contemporary

\footnotetext{
22 Law $12,651 / 2012$.

${ }^{23}$ For instance, the hydroelectric plant of Belo Monte, in the state of Pará.

${ }^{24}$ Complementary Law n. 140/2011.
} 
trends - characterized by a significant number of environmental organizations as the "moment of greatest setback and retrocession in the socio-environmental agenda, since the end of the military dictatorship" (sic) - identifiable since the middle of the first Rousseff administration (2011-2014) ${ }^{25}$.

\section{THE MUNICIPALITY WITHIN THE ENVIRONMENTAL INSTITUTIONAL FRAMEWORK}

Five institutional factors, discussed below, emerge from the review of the environmental institutionalization process as key driving forces regarding the agency of municipalities in the environmental realm. The discussion below highlights the importance of each of these factors: the nature of municipal autonomy in light of Brazilian federal organization, the inclusion of environmental protection as a Federal Constitution provision, the role of sources of funding within the institutional arrangement for environmental protection, the diverse legal regimes embraced by environmental institutional framework building, and the indeterminacy of the environmental law $v i s$ - $a$-vis of the exercise of discretionary powers by environmental bureaucracy.

The first factor encompasses the specific traits of municipal autonomy in light of the status as a federative entity that Brazilian municipalities achieved in the Constitution of 1988. The model of federalism inaugurated at this time brought to Brazilian municipalities a "massive institutional transformation" (MELO, 1996), whose effects have not yet been studied in depth. Constitutional provisions changed the previous attribution of roles among subnational governments: they strengthened the municipalities, consolidating their powers regarding matters already within their sphere of responsibility and formally expanding their authority to new areas including the environment, with new powers deriving from the new condition. The status as a federative entity brought a new kind of autonomy to the 5570 municipalities, allowing them to exercise their enhanced competencies in an unprecedented way. Federative status brought about the power to promulgate municipal Organic Law (corresponding to a local constitution - this power was previously delegated to the states), political autonomy (i.e., the power to elect their own authorities, extinguishing the possibility of mayors being appointed, as done under the military dictatorship), the granting of exclusive responsibilities, an increased responsibilities held jointly with other entities, and the development of a tax-levying

\footnotetext{
${ }^{25}$ See in ISA; IDS; SOS Mata Atlântica; IPAM; Instituto Vitae Civilis; RMA; Rede GTA; APREMAVI; WWW Brazil, 2012.
} 
base $^{26}$. In light of the current federal organization, municipal autonomy is defined as the power to govern its own affairs with unique responsibilities, within a scope defined by a higher authority in the political, administrative and fiscal spheres, supported by self-generated and transferred resources ${ }^{27}$.

Formally, there is only one aspect that differentiates municipalities on the one hand, and the states and the Federal government, on the other, and which does not otherwise affect municipal status. It is related to the composition of the municipal government, which consists of only by the executive branch (mayor and secretariats) and the council of aldermen - there is no judicial municipal body. Comparing to other federal countries, it should be also highlighted that Brazilian municipalities have no representatives in the legislative assemblies of any other federal entities (the states and Federal government).

There is a wide range of autonomy arrangements for local governments throughout the world: attaining this status placed the Brazilian municipalities in a leading position internationally, with regard to local government autonomy within federal structures. From their own perspective, they never had this much autonomy, prior to the Constitution of $1988^{28}$. However, the according of status does not "automatically" reflects the de facto situation: the capabilities that materialize autonomy must be built. A set of capabilities supports the practice of this autonomy: the capacity for self-organization, through the development of local Organic Law and elaboration of specificlegislation across the areas of their competence ${ }^{29}$; the capacity for self-government, through the election of a mayor and aldermen; the capacity for self-administration, including the power to provide services of local interest, levy taxes, and allot revenue ${ }^{30}$; and the exercising of administrative police power, inherent to a municipality's attributes (SILVA, 2009; MEIRELLES, 2014). Preconditions for municipal autonomy also include

${ }^{26}$ Municipal tax revenue is, since 1965, responsible for levying the Tax on Urban Land Property (IPTU - Imposto sobre Propriedade Territorial Urbana), Service Excise Tax (ISS - Imposto sobre Serviços). Municipalities also started after 1988 levying Real Estate Transfer tax, (ITBI - Imposto sobre Transmissão de Bens Imóveis) and a Fuel Tax, as well as enjoying more favorable rules for the composition and distribution of resources from the federal, all-important Municipalities Participation Fund.

${ }^{27}$ In this case, the Federal Constitution.

${ }^{28}$ Souza (2005) reports different views on this autonomy, throughout history until the 1980s. The author identifies three currents: the first "emphasizes the hegemony of local politics and of vested interests in the power structure in Brazil," the second assumes that the central government has always played a major role in Brazilian politics, and the third takes an intermediate position, according to which there is "a strong interdependence between the local and central levels, generating mutual legitimacy."

${ }^{29}$ Federal Constitution, art. 29.

${ }^{30}$ Federal Constitution, arts. 29-31, 156 and 159. 
actions that enable the construction of the municipality as a political entity capable of enforcing the rule of law within its territory once it is assumed that the republican State is "a democratic State that derives its power and legitimacy from the support of civil society ... and democratic institutions" (PEREIRA, 2001, p.478). Overcoming the path-dependency related to the clientelistic practices that have for a long time characterized broad sectors of public administration presents a significant challenge.

It is essential to adopt a historical perspective in order to adequately understand the issues that constitute the objects of local policies ${ }^{31}$. More than spatial cut outs for political-administrative purposes, the 5,570 Brazilian municipalities are territorial, social, and historical realities whose economic, social, demographic, fiscal, and environmental characteristics form an extraordinarily diverse picture. The heterogeneity is such that, for Affonso (2003), the term "municipality" comprises realities "with remarkably scant common content," undermining decentralization efforts (ARRETCHE, 1999). In spite of the fiscal and political mechanisms to offset economic disparities among states and municipalities, and the deep changes in the federation as a consequence of redemocratization and decentralization, municipal capabilities to respond to their agendas are "highly uneven" (SOUZA, 2002). So, any policy arrangements for environmental protection that rely on "one size fits all" approaches should be discarded. Local environmental agendas will be extremely diverse and heterogeneous.

Moving on, in federal countries the exercising of autonomy by subnational entities is not conditioned only by structural and political factors and the required administrative, managerial, and institutional capabilities. Subnational action within a federal system presupposes a balance between self-rule and shared-rule (WATTS, 1998), interdependent action among subnational entities and among subnational entities and the federal government. Therefore, institutional arrangements that adequately equate interdependent action and balance autonomous with interdependent action are essential to subnational governments in Brazil. The federative relations are, in essence, based on negotiation and agreement, as highlighted by Affonso (2003): federalism is characterized by territorialized bargaining among collective actors.

In Brazil, to date lax intergovernmental relation and predatory competition have prevailed. The municipal realm is plagued by persistent local autarchic management concepts ("municipal Hobbesianism," according to Melo (1996)), and several "pockets" remain resistant to transparency and democratic accountability (ABRUCIO, 2005, p. 48),

\footnotetext{
${ }^{31}$ Both to decide (policy decision making) and to implement and enforce (policy making), a distinction underscored by Arretche (2010).
} 
interacting with the distortion called "executivism" (CARVALHO, 2003b; JOFFRE NETO, 2003). Adopting the perspective summarized by Abrucio and Soares (2001), reflection on the possibilities and limits of autonomous municipal action must shift from the dichotomy "autonomy versus dependence" to the field of relations between autonomy, interdependence, mutual checks and balances, and cooperation. The existence of mechanisms for coordination, cooperation, and redistribution is a sine qua non condition for the quality assurance of a minimum performance level for all municipalities.

In summary, municipal autonomy should not be taken as self-sufficient, even in the case of the exclusive competencies. The exercise of local autonomy is bounded in the first place by the capacities and resources needed to implement local policies. Secondly, the federal organization of the Brazilian state implies that local policies are often the product of a complex interaction between municipal initiatives grounded in self-rule and municipal actions dependent on intergovernmental cooperative regimes, grounded in shared-rule. The exercise of autonomous action is embedded on the institutional federative framework, which encompasses intergovernmental relations for cooperative actions, regional and national coordination, and adequate checks and balances, and on the unique historical development of each municipal jurisdiction.

The second factor concerns the constitutional provisions in place for environmental protection. The Brazilian federal system delineates two kinds of competencies: legislative and material (executive) powers. The stewardship of the environment is a constitutional provision, defined as an object of common jurisdiction among the three spheres of government. In the environmental domain municipalities exercise both material and legislative powers. Regarding material competence, municipalities have full material responsibility over the environment, conjointly with the states and the federal government. Municipal legislative power is exercised over local interests and supplements federal and state legislation when applicable.

For issues under common responsibility such as environmental protection, federal systems involve building governance arrangements that support the exercise of joint responsibility through coordination mechanisms, vertical and horizontal cooperation systems ruling the exercise of common function, instruments for checks and balances, compensation mechanisms to balance disparate capabilities between subnational entities and, particularly, regular and reliable sources of funding.

These arrangements are distinct for each area of public policy; in the case of environmental policy, however, they have not yet been fully set forth in Brazil. The only rules explicitly geared to the exercise of a shared environmental mandate among the federal entities, contained in Complementary Law 140/2011, bypass the construction of these arrangements entirely. Focusing mainly on environmental permitting and inspecting, the approach adopted in this law deals only with the actions for environmental 
control of each level of government as distinct and separate entities. With regard to cooperation mechanisms it merely refers to those that already exist: public consortia, agreements, technical cooperation, federative commissions, funds, and delegation of duties $^{32}$. Moreover, it contains provisions considered constitutionally questionable (see, for example, MACHADO, 2013).

Currently, there are in place numerous government agencies dealing with the environment at all levels of government. However, they are isolated from the "hard core" of the government, which makes the big decisions affecting the economy and development; they do not have much contact with the tax-levying sphere; they lack clear binding rules of conduct; have very little recourse to cooperation mechanisms and consequently face difficulty in systematically inducing environmentally aware behaviours in other sectors such as agriculture, energy, transportation, and regional development; and they are without any regular source of funding for the key activities of the environmental mandate.

There is indeed a wide field in which municipalities can act on their own, without support from federal and state governments: municipalities are free to establish their own environmental priorities and negotiate their participation in state and federal priorities. One of the main limits to independent municipal action is its effective fiscal, spending and technical capacities.

The third factor refers to the lack of rules regarding the sources of funding for the environmental mandate. It is urgent that this issue be addressed. To date there are no regular, stable sources of funding for state action for the environment. Existing sources of municipal environmental funding are municipal treasuries and environmental financing funds instituted at the three governmental levels. These provide grants (both refundable and non-refundable) after project proposals are accepted - not to mention other mechanisms supposed to foster municipal environmental spending, such as the "Ecological VAT" (ICMS Ecológico) ${ }^{33}$. Mechanisms such as environmental funds are, however, unable to meet the essential demands of the environmental mandate, such as permanent funding for environmental control and planning.

Municipal environmental spending must be analysed in light of the structure of municipal financing. In the national context, municipal finances are marked by a contrast-ridden panorama and usually a limited capacity to fund their own policies as has been analysed in detail (PRADO, 2003; REZENDE, 2003). Most municipalities

32 LC 14 n. 0/2011, Article 4\%.

33 At the federal level, environmental-financing funds include the National Environmental Fund, the recently established National Fund on Climate Change, and the Amazon Fund. 
rely heavily on the tax revenue transfer system. According to Prado, the transfer system via the Municipalities Participation Fund establishes a random, regressive distribution, while voluntary transfers such as Congress-allotted funds are a prestigious bargaining chip in politics. Even those municipalities that do not utterly depend on intergovernmental transfers suffer from structural limits in their tax-collection apparatuses. The poor performance of local economies will often deepen these limitations. With reference to the freedom to allocate financial resources, municipal initiatives are divided into two groups: those funded by "mandatory spending", and those by "free" or "discretionary spending." Initiatives may rely on guaranteed revenue through mandatory spending, either because the revenue collected was allotted to a cost item such as health, or because of the sum revenue a proportional minimum is of mandatory allotment to certain cost items(such as both health and education). Other municipal programs and initiatives must, in turn, vie for "free" budgetary resources in each fiscal period when the budget is voted upon - and the environmental mandate lies in this group. In addition to these, there are other financial constraints to municipal public spending to consider, originating in the fiscal adjustment, the control of public spending imposed by the Law of Fiscal Responsibility (2000), and in the decision to accumulate a surplus of resources kept in contingency for payment to creditors.

Therefore, municipal action with regard to environmental protection depends, first, on the effective availability of "free" revenue, and second, on the political goodwill to support the allocation of these resources to the environment (in permanent competition with other areas struggling for freely allocated funding such as urban development, sanitation, infrastructure, and culture). Therefore, municipal environmental initiatives and programs tend to have limited self-funding capability. Municipalities are, more than ever, highly dependent upon vertical and horizontal intergovernmental cooperation for implementing their environmental policies (NEVES, 2012).

The fourth factor concerns the coexistence of different regulatory regimes related to environmental resources. Kraft (2001, p. 12) stresses that "we do not find environmental policy set out in any single decision or statute. Rather it is the aggregate of statutes, regulations, and court precedents (...)”. Brañes (2001) points out that this is a common feature of environmental law in many countries. The "properly environmental" rules, corresponding to the systemic framework, are related to the environment itself, object of the stewardship of the state and of related public policies. In Brazil, the systemic definition of the environment is provided in Law 6938/1981: it is "the set of conditions, laws, influences and interactions of physical, chemical and biological order, which shelters and governs life in all its forms". In this context the three tiers of the government are conjointly responsible for environmental action over the long term, on behalf of both current and "future generations" (Federal Constitution, art. 
225, heading). In addition to the Constitution, essential institutional references include Complementary Law 140/2011, which is supposed to deal with the forms of cooperation between the spheres of government under the environmental mandate; the aforementioned Law for National Environmental Policy of 1981, to which is added a group of rules and standards including the punishments for environmental crimes (1998), the consolidation of conservation area categories (2000), and the national policy for environmental education.

This environmental legal framework stricto sensu coexists with sector-by-sector regulations supported by diverse political and philosophical frameworks (those for water management, forests, flora, and fauna protection are eloquent examples), which shape the role of the municipality very differently according to the regulatory object (NEVES, 2014). As a result, the municipality's role in environmental stewardship assumes extremely diverse forms according to the regulatory object, unveiling a broad gradient of local government involvement according to the applicable interpretations, which is an ongoing and adaptive process.

The fifth factor is the indeterminacy of environmental law and policies and the consequent need of building bureaucratic capacities in order to interpret regulatory application. Torres(1996, p.141) identifies two aspects of environmental law's complexity: "its indeterminacy and its obscurity". Drawing on Habermas, Azuela de la Cueva (2006) contends that there are several causes for uncertainty within environmental law, among which are scientific uncertainty regarding environmental problems, the permanent change characteristic of scientific knowledge, the presence of non-scientific elements in the process of establishing the legal framework, and the different schools and manners of legal reasoning in the individual cases where the rules and standards are to be applied. Azuela de la Cueva (2006) reflects on the inescapable indeterminacy of environmental rules, i.e. their inability to contain and define in themselves all the conditions for their implementation, through the concept of "process of juridification of the environmental issue":

This is the most important manifestation, though not the only one, of one of the most important characteristics of legal experience in complex societies: indeterminacy.... By juridifying the environmental issue, it is made subject to the conditions specific to the legal field, regardless of its potential to introduce new elements. (AZUELA DE LA CUEVA, 2006, p. 70, our translation)

Environmental issues that are the object of state action are indeed varied and highly interconnected, characterized by uncertainty and complexity. Territorial, political-administrative, and social boundaries are crossed, etching complex networks 
of physical and social causality. Environmental issues beget the production of specialized scientific knowledge and the use of sophisticated technologies. However, permanent deficit in scientific knowledge regarding the objects of policy limits the availability of inputs for decision-making processes, when several are still poorly known. The high degree of complexity of the objects of policy means the scale of environmental problems tend to be minimized in the medium- and long-term, with clashes between supporters of the cautionary principle and the supporters of laissez-faire (CONNELLY and SMITH, 1999; KETTL, 2002; LAFFERTY and MEADOWCROFT, 1996; STEEL; CLINTON and LOVRICH, 2003).

The demand for a solid scientific basis for the design of environmental policies including the definition of new requirements and laws - involves the contribution of experts and technicians capable of handling methodologies and tools of great technical complexity. This structuralizing feature of environmental policy bestows a prominent role in the policy-making process upon the scientific community and the formation of an environmental bureaucracy. This last entity must be able to design and implement programs and make the key decisions in environmental management, beginning with the exercise of power by those who enforce environmental regulations, a role at the heart of the environmental mandate. Material competence over the environment brings as a logical consequence police power, or rather the power of administrative police, applied to environmental protection. Police power is the power available to the Public Administration to exercise control over property and persons for the benefit of the collectivity or the State itself (MEIRELLES, 2014). The police power affects assets, rights, and activities, and spreads throughout the Public Administration through orders and prohibitions, but above all, by limiting and punitive standards - that is, "by order of the police, by consent of the police, and by sanction of the police" (MOREIRA NETO, 1976, p.309, apud MACHADO, 2014). The power of administrative police over the environment is exercised through various activities, such as the supervision of activities and behaviours, environmental permitting and several permitting-related measures, including record keeping (such as via the Rural Environmental Registry), monitoring (e.g., of environmental resources, of compliance with requirements defined in permits and in Terms of Adjustment of Conduct), and the application of sanctions.

The environmental bureaucracy enjoys wide discretionary powers for the interpretation of generically formulated rules, to exercise police power, and to control and apply sanctions. Several other environmental policy procedures also require significant discretionary powers, such as permitting based on Environmental Impact Assessments, and Terms of Adjustment of Conduct (TAC - Termos de Ajustamento de Conduta), which includes the payment of financial compensation for environmental damages. 
In brief, the indeterminacy of environmental regulation derives from the complexity of the environment as an object of public policy, and calls for the exercise of discretion by the environmental protection authorities and bureaucracy. The construction of a specialized technical staff of state officials, a highly qualified environmental bureaucracy, is paramount: effective environmental policies depend heavily on the existence of highly skilled state bureaucracies, capable of interpreting environmental regulations and exerting environmental discretionary power. The nurturing and development of environmental policy capabilities represents an important challenge to local governments, given the scarce financial resources available up to now for environmental governance.

\section{CONCLUSION}

The present inquiry's main objective was to identify the institutional landmarks explaining the role assigned to subnational governments, particularly municipalities, in environmental protection in Brazil. A review of the development of Brazilian environmental regulation reveals a wide range of institutional issues that have and will do much to mold municipal policies for environmental protection. Over the period 1970s-2010s, significant progress has been made in terms of institutional changes and the establishment of the national environmental regulation. Currently, the environment is unequivocally defined as a resource of public and collective interest and under the state's stewardship.

Without any pretence of exhausting the topic, five institutional aspects were selected, according to their importance in shaping institutional landscape for environmental protection: the constitutional provisions on the municipal status, the constitutional provisions on the distribution of powers of environmental stewardship, the path followed by the institutionalization of environmental regulation, the issues related to environmental policy funding, and the discretionary powers of the environmental bureaucracy originated by the indeterminacy of environmental law. They provide a complex picture of the role of municipalities in the national environmental governance system. The three levels of government are invested with a constitutional mandate for environmental protection, with specified institutional conditions for implementation and operation. The empowerment of Brazilian municipalities (currently numbering 5,570) as federated entities is an important institutional change with regard to environmental protection but which must be qualified in light of a set of factors. Brazilian municipalities are empowered to the full exercise of the environmental mandate. The autonomy typical of a federated entity provides municipalities with an unprecedented freedom of action in the environmental 
domain. However, there are conditions that determine the viability of autonomous action: in particular, the institutional arrangements for enforcing environmental "shared rules," the capacity-building process and outcomes, environmental-spending capacity, and the extraordinary heterogeneity of municipalities and their diversity. The combination of these factors causes this autonomy to be exercised very differently, in few cases effectively, often quite precariously, by municipalities.

Environmental protection is the responsibility of all tiers of government, increasing the complexity of the arrangements necessary for the execution of policies and emphasizing the plurality of actors. By focusing on the isolated action of each of the three levels, the primary objective of the Complementary Law n. 140/2011 that should rule cooperation arrangements is distorted. Especially dramatic is the absence of an institutional architecture that would enable cooperation among federal, state, and municipal entities on behalf of the environment, coordination capacity, and resolution of federative conflicts, considering the manifold demands and the sheer number of state actors responsible for the environmental mandate. The consequence, for municipalities, is that they are most often quite alone in fulfilling their mandate. Without a regular source for environmental funding, municipalities are, more than ever, highly dependent upon vertical and horizontal intergovernmental cooperation in order to implement environmental policy.

The constitutional distribution of competencies among the three levels of government has assigned municipalities a set of exclusive areas of jurisdiction in which environmental concerns may be mainstreamed. The municipal environmental agenda has both a "core" of activities common to all municipalities and other activities selected according to local interests, which makes each municipal agenda unique.

Analysing the institutional landscape of local environmental action, municipalities are fully empowered to protect the environment and to mainstream environmental concerns in local policies. Municipal autonomy and discretionary power held by local environmental bureaucracy reinforce their constitutional role. However, shortcomings in the environmental federal arrangement undermine municipal action up to now. Capacity building for local environmental governance is a crucial factor: the effective empowerment of municipal governments depends on the construction of capacities to fully exercise their duties and adequately exercise their discretionary powers in environmental decisions.

There is a glaring contradiction between theinstitutional foundations for environmental protection and the weakness of the institutional arrangements adopted to implement this protection and fund its operation: the improvement of municipal environmental performance depends on the strengthening of the federative arrangement for environmental protection: it is not possible for municipalities to fully respond to the agenda if there is not a supporting national strategy involving the federal and state governments. 


\section{REFERENCES}

ABRUCIO, F. L. A coordenação federativa no Brasil: a experiência do período FHC e os desafios do governo Lula. Revista de Sociologia e Política, Curitiba, n. 24, p. 41-67, jun. 2005.

AFFONSO, R. B. A. O federalismo e as teorias hegemônicas da economia do setor público na segunda metade do século XX: um balanço crítico. Tese (Doutorado em Economia) Instituto de Economia, Universidade Estadual de Campinas, Campinas, 2003.

ARRETCHE, M. Políticas sociais no Brasil: descentralização em um Estado federativo. Revista Brasileira de Ciências Sociais, vol. 14, n. 40, junho 1999, p. 11-141.

ARRETCHE, M. Federalismo e igualdade territorial: uma contradição em termos? DADOS Revista de Ciências Sociais, v. 53, n. 3, p. 587-620, 2010.

AZUELA DE LA CUEVA, A. Visionarios y pragmáticos: una aproximación sociológica al Derecho ambiental. México: Fontamara/Universidad Nacional Autónoma de México, 2006.

BENJAMIN, A. H. “Introdução ao direito ambiental brasileiro”. In: SOARES JR, J.; GALVÃO, F. (Coord.). Direito ambiental na visão da magistratura e do Ministério Público. Belo Horizonte: Del Rey, 2003, p. 11-118.

BERNARD, E. et al. Downgrading, downsizing, degazettement and reclassification of protected areas in Brazil. Conservation Biology, v. 28, n. 4, p. 939-950, Aug. 2014.

BRAÑES, R. El desarrollo del derecho ambiental latinoamericano y suaplicación: informe sobre los cambios jurídicos después de la Conferencia de las Naciones Unidas sobre el Medio Ambiente y el Desarrollo (Rio 92). Santiago de Chile: Programa de las Naciones Unidaspara el Desarrollo y Oficina Regional de la UNESCO para América Latina y el Caribe, 2001.

BRAÑES, R. Manual de derecho ambiental mexicano. México, DF: Fondo de Cultura Económica, 2000.

CARVALHO, J. C. "A vocação democrática da gestão ambiental brasileira e o papel do Poder Executivo". In: TRIGUEIRO, A. (Coord.). Meio ambiente no Século 21: 21 especialistas falam da questão ambiental em suas áreas de conhecimento. Rio de Janeiro: Sextante, 2003a, p. 259-274.

CARVALHO, J. C. "Discurso de abertura do Encontro Interestadual do Ministério Público e da Magistratura para o Meio Ambiente, Araxá, MG, 10 abr. 2002”. In: SOARES JUNIOR, J.; GALVÃO, F. Direito ambiental na visão da Magistratura e do Ministério Público. Belo Horizonte: Del Rey, 2003b, p. 1-10.

CONNELLY, J.; G. SMITH. Politics and the environment: from theory to practice. 2. ed. London: Routledge, 2003.

EVANS, P. The future of the State. Globalization Trend Lab 2014. The Joseph H. Lauder Institute. Philadelphia: University of Pennsylvania, 2014.

FARAH, M. F. S.; JACOBI, P. Governos locais e cooperação inter e intragovernamental no Brasil. In: FARAH, M.; BARBOSA, H. B. (Orgs.). Novas experiências de gestão pública e cidadania. São Paulo: FGV, 2000.

HODGSON, G. What are institutions? Journal of Economic Issues, v. 40, n. 1, Mar. 2006. 
ISA - INSTITUTO SOCIOAMBIENTAL. Estudo do ISA revela que nova Lei Florestal trouxe retrocesso ambiental em três municípios do Xingu. ISA, Notícias Socioambientais,08/06/2015. Disponível em: <http://www.socioambiental.org/pt-br/noticias-socioambientais/estudo-do-isa-revela-que-novo-codigo-florestal-trouxe-retrocesso-ambiental-em-tres-municipios-do-xingu-mtpa>. Acesso em: 10 jun. 2015.

ISA - INSTITUTO SOCIOAMBIENTAL ET AL. Retrocessos do governo Dilma na agenda socioambiental. 6 de março de 2012. Disponível em: <http://www.wwf.org.br/informacoes/?30765/ Carta-de-repdio-aos-retrocessos-na-poltica-ambiental-do-Brasil>, Acesso em: 10 jun. 2015.

JOFFRE NETO, J. M. Câmaras municipais no Brasil: ascensão e declínio. Taubaté, SP: 2003.

KETTL, D. (Ed.). Environmental governance: a report on the next generation of environmental policy. Washington, DC: Brookings Institution Press, 2002.

LAFFERTY, W.; MEADOWCROFT, J. "Democracy and the environment: congruence and conflicts - preliminary reflections”. In: LAFFERTY, W.; MEADOWCROFT, J. (Ed.). Democracy and the environment - problems and prospects. Chettenham: Edward Elgar, 1996, p. 1-17.

MACHADO, P. A. L. Direito Ambiental Brasileiro. 22. ed. São Paulo: Malheiros, 2014.

MARCHESAN, A. M. M.; STEIGLEDER. A. M. Crimes ambientais. Comentários à lei $n$. 9605/1998. Porto Alegre: Livraria do Advogado Ed., 2013.

MCALLISTER, L. Making law matter: environmental protection and legal institutions in Brazil. Palo Alto, CA: Stanford University Press, 2008.

MEIRELLES, H. L. et al. Direito Administrativo Brasileiro. 40. ed. São Paulo: Malheiros, 2014.

MEIRELLES, H. L. Direito Municipal Brasileiro. DALLARI, A.A. (Coord.). 17. ed. São Paulo: Malheiros, 2014a.

MELO, M. Crise federativa, guerra fiscal e "hobbesianismo municipal": efeitos perversos da descentralização? São Paulo em Perspectiva, v. 10, n. 3, p. 11-20, 1996.

MILARE, E. Direito do meio ambiente. 9. ed. São Paulo: Revista Editora dos Tribunais, 2014.

NEDER, R. T. Crise Socioambiental: Estado \& sociedade civil no Brasil (1982-1998). São Paulo: Annablume; FAPESP, 2002.

NEVES, E.M.S.C. Política ambiental, municípios e cooperação intergovernamental no Brasil. Revista do Instituto de Estudos Avançados USP, n. 74, 2012.

NEVES, E. M. S. C. Política e gestão ambiental no contexto municipal. Cadernos Adenauer XV - Governança e sustentabilidade das cidades, Rio de Janeiro: Fundação Konrad Adenauer, dez. 2014.

PÁDUA, J. A. Annihilating natural productions. Nature's economy, colonial crisis and the origins of Brazilian political environmentalism (1786-1810). Environment and History, v. 6, p. $255-287,2000$.

PEREIRA, L. C. B. “Do Estado patrimonial ao gerencial”. In: SACHS, I. et al. (Org.) Brasil, um século de transformações. São Paulo: Companhia das Letras, 2001, p. 472-487.

PRADO, S. "Distribuição intergovernamental de recursos na Federação brasileira". In: REZENDE, F.; OliVEIRA, F. A (Orgs.). Descentralização e federalismo fiscal no Brasil, desafios da reforma tributária. Rio de Janeiro: Konrad Adenauer Stiftung, 2003, p. 41-126. 
REZENDE, F.; AFONSO, J. R. A Federação brasileira: fatos, desafios, perspectivas. In: REZENDE, F.; OLIVEIRA, F. A. (Org.). Federalismo e integração econômica regional - desafios para o Mercosul. Rio de Janeiro: Konrad Adenauer, 2004, p. 301-362.

SILVA, J. A. Direito ambiental constitucional. Rio de Janeiro: Malheiros, 2009.

SILVA-SANCHEZ, S. S. Cidadania ambiental: novos direitos no Brasil. São Paulo: Humanitas: EDUSP, 2000.

SOUZA, C. Brazil: the prospects of a center-constraining federation in a fragmented polity. Publius, v. 32, n. 2, p. 3-22, Spring, 2002.

SOUZA, C. Federalismo, desenho constitucional e instituições federativas no Brasil pós 1988. Revista de Sociologia e Política, Curitiba, n. 24, p. 105-121, 2005.

STEEL, B. et al. Environmental politics and policy. Boston: McGraw-Hill, 2003.

TORRES, G. Developments in environmental law. The Georgetown Law Journal, University of Minnesota, v. 83, 1996.

TOSTES, A. Sistema de legislação ambiental. Petrópolis: Vozes; Rio de Janeiro: CECIP, 1994.

VALLE, R. S. T. O ano de 2010 pode aprofundar retrocesso na política socioambiental brasileira. ISA, Notícias Socioambientais, 11/02/2010. Disponível em: <http://www.socioambiental. org/nsa/direto/direto_html?codigo=2010-02-11-113943>.

VATN, A. Institutions and the environment. Cheltenham: Edward Elgar Publishing Limited, 2005.

WATTS, R. L. Federalism, federal political systems, and federations. Annual Review of Political Science, n. 1, p. 117-137, 1998.

YOUNG, O. et al. (Ed.). Institutions and environmental change. Principal findings, applications and research frontier. Cambridge: The MIT Press, 2008. 